\title{
Паалеогляциология
}

УДК 551.583.7; 551.324 .8

\section{The Mid-Pleistocene Transition and the Vostok Oldest Ice Challenge}

\author{
(C) 2015 r. V.Ya. Lipenkov' ${ }^{1}$, D. Raynaud ${ }^{2}$ \\ ${ }^{1}$ Arctic and Antarctic Research Institute, St Petersburg; \\ ${ }^{2}$ Laboratoire de Glaciologie et Géophysique de l'Environnement, Grenoble, France \\ lipenkov@aari.ru
}

\section{Климатическая перестройка в середине плейстоцена и проблема исследования древнейшего антарктического льда со станции Восток}

\author{
В.Я. Липенков ${ }^{1}$, Д. Райно ${ }^{2}$ \\ ${ }^{1}$ Арктический и Антарктический научно-исследовательский институт, Санкт-Петербург; \\ ${ }^{2}$ Лаборатория гляциологии и геофизики окружающей среды, Гренобль, Франция
}

Статья принята к печати 6 сентября 2015 г.

Antarctica, carbon dioxide, disturbed ice, hydrates, ice dating, Mid-Pleistocene Transition, oldest ice.

Антарктика, гидраты, датирование льда, деформированный лёд, диоксид углерода, древнейший лёд, климатическая перестройка, плейстоцен.

Marine records indicate a dramatic change in the predominant periodicity of climate variability, from about 40 ka to about 100 ka around one million years ago. The reason for this major climatic shift, which is called the Mid-Pleistocene Transition or MPT, remains unknown - and is of great interest to the climate scientist. Could the core of the oldest meteoric ice bedded at Vostok between 3310 and 3539 m, which has experienced severe deformation, nevertheless be useful in deciphering some of the aspects of the MPT enigma? Reflecting upon this question and considering the available data from the disturbed section of the ice core, we feel impelled to propose a new project focused on the oldest Vostok meteoric ice, which could be named the Vostok Oldest Ice Challenge or VOICE.

Результаты исследований морских донных осадков показывают, что около 1 млн лет назад изменился характерный период климатических колебаний, связанных с чередованием ледниковых и межледниковых эпох: циклы в 40 тыс. лет сменились циклами в 100 тыс. лет. Причины, которые привели к перестройке климатической системы планеты в середине плейстоцена (Mid Pleistocene Transition - MPT), пока не известны и приковывают к себе пристальное внимание климатологов. Может ли керн древнего деформированного льда, залегающего в районе станции Восток в интервале глубин 3310-3539 м, дать ответы хотя бы на часть вопросов, связанных с генезисом МРТ? В статье анализируются предварительные результаты изучения этого керна и обосновывается программа дальнейших углублённых исследований древнейшего антарктического льда со станции Восток под общим названием Vostok Oldest Ice Challenge (VOICE).

\section{Introduction}

Over the last few decades, the deep ice cores drilled at Russia's Vostok Station have provided a wealth of information about past climate and environmental changes. At this East Antarctica site, the ice thickness amounts to $3770 \mathrm{~m}$ and the snow accumulation rate is only $2.1 \mathrm{~cm}$ of water equivalent per year. This gives us the unique opportunity to obtain a long climatic record with a relatively high time resolution. In 1998, drilling operations in the deep $5 \mathrm{G}$ borehole, conducted at that time as a collaborative project between Russia, France and the United States, reached a depth of $3623 \mathrm{~m}$. At $3539 \mathrm{~m}$ below the surface, the drill penetrated into the ice refrozen from water from Lake Vostok, a deep subglacial water body which extends below the ice sheet over a large area. After a long break, the drilling was resumed in January 2006. Finally, in February 2012, the drill reached the surface of Lake Vostok for the first time, at a depth of $3769 \mathrm{~m}$.

The whole $5 \mathrm{G}$ ice core can be separated into three distinct sections (Fig. 1). The upper $3310 \mathrm{~m}$ of the core are characterised by an undisturbed sequence of meteoric ice layers. Analysis of this section of the core has resulted in the first Antarctic ice record of atmospheric composition and climate extending through four climate cycles back to $420 \mathrm{kyr}$ BP [31]. Between 3310 and $3539 \mathrm{~m}$ there are indications of ice-flow anomalies that could alter the original stratigraphy of meteoric ice. Finally, between $3539 \mathrm{~m}$ and the icewater interface at a depth of $3769 \mathrm{~m}$, the core consists of ice accreted at the bottom of the Antarctic ice sheet from Lake Vostok's water.

The Vostok ice cores which represent the upper section of the meteoric ice $(0-3310 \mathrm{~m})$ and the $230 \mathrm{~m}$ thickness of accreted ice (3539-3769 m) have been comprehensively analysed and have received 


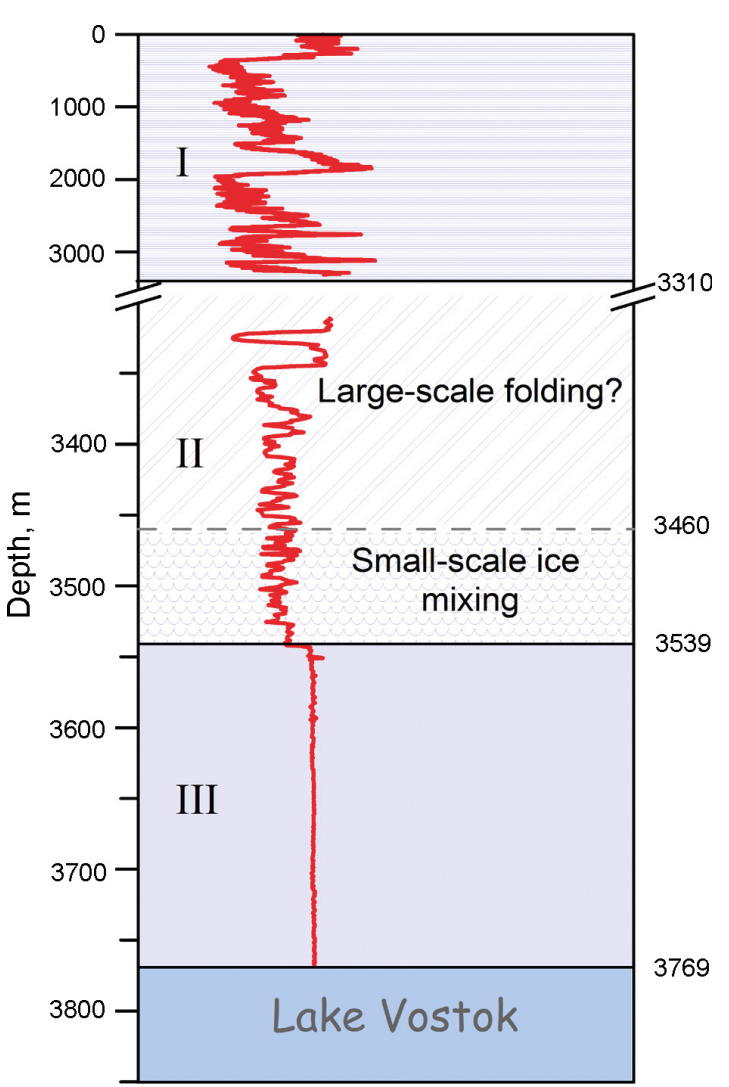

Fig. 1. Schematic representation of the vertical structure of the Antarctic ice sheet in the vicinity of Vostok station: I - undisturbed section of the Vostok meteoric ice containing continuous climatic record $(0-3310 \mathrm{~m})$; II - disturbed section of the meteoric ice (3310-3539 m), in which two distinct strata can be discerned: in the stratum between 3310 and $3460 \mathrm{~m}$ a large-scale folding of ice is presumed, in the stratum between 3460 and $3538 \mathrm{~m}$ the submetric scale ice interbedding is observed; III - accreted ice refrozen from Lake Vostok's water. The deuterium profile is composed from available published data $[1,31,40]$ (axis is not shown)

Рис. 1. Схематическое изображение вертикального строения антарктического ледника в районе станции Восток.

I - атмосферный лёд с ненарушенным залеганием слоёв, содержащий непрерывную информацию о прошлых изменениях климата (0-3310 м); II - атмосферный лёд с несогласным залеганием слоёв (3310-3539 м), в котором выделяются два пласта: в интервале глубин 3310-3460 м обнаружены признаки складчатой деформации льда с размером складок в первые десятки метров; для интервала 3460 3539 м характерно мелкомасштабное (в масштабе $10^{-2}$ $10^{-1}$ м) перемешивание слоёв льда; III - конжеляционный лёд, образовавшийся из воды оз. Восток. Изотопный профиль $(\delta \mathrm{D})$ построен по опубликованным данным $[1,31$, 40] (шкала $\delta \mathrm{D}$ не показана)

extensive coverage in the scientific literature, including a number of top, widely cited papers related to past climate change and exploration of Antarc- tic subglacial environments. Meanwhile, the oldest meteoric ice, bedded between 3310 and 3539 m, has seen much less attention. Earlier works have shown that complex ice deformation, which has occurred when the ice was still grounded upstream from Vostok Station, resulted in the folding and intermixing of ice at a submetric scale in the stratum bedded below 3450-3460 $\mathrm{m}$ and at a larger scale between 3310 and $3450 \mathrm{~m}$ (see Fig. 1) [18, 39-41]. Using an appropriate correction of the ice stratigraphy for flow disturbance in the 3320-3345 m interval, it has only been possible to extend the Vostok ice record further back to $440 \mathrm{kyr}$ BP, which implies full coverage of the Marine Isotope Stage (MIS) 11 [36]. Because of the ice mixing and the diffusive smoothing of the climatic signals, extracting useful paleoclimatic information from the deeper section of the Vostok disturbed ice is a challenging problem. The aims of our paper are: (a) to explain our motivation to tackle this difficult task, (b) to discuss the old and new data relevant to this issue, and (c) to present a new project focused on the oldest Vostok meteoric ice, referred to from now on as the Vostok Oldest Ice Challenge or VOICE.

\section{The enigma of the Mid-Pleistocene Transition}

During the Pleistocene, roughly the last 2.5 million years, the Earth's surface has known a series of glacial-interglacial cycles stimulated by changes in the distribution of the solar radiation reaching the Earth's surface, themselves driven by the periodicities of the Earth motion around the sun (about 100 and $400 \mathrm{ka}$ ) and of changes in the tilt (41 ka) and direction ( 23 and $19 \mathrm{ka}$ ) of Earth's rotation axis. These oscillations are well imprinted in the long deep-sea sediment records [20] but surprisingly, they indicate a systematic change in the predominant periodicity from about 40 to about 100 ka around one million years ago, although there is no marked change in the insolation signal driven by the Earth's orbital parameters (Fig. 2). This is called the Mid-Pleistocene Transition and is a major, if not the key Pleistocene enigma yet to be solved.

Conceptually, it is possible to shift from a 'rapid' to a slower oscillation by adding a long trend. This is what Paillard [27] and Paillard and Parrenin [29] showed by using a simple conceptual model with multiple equilibria (threshold model) in the climatic 


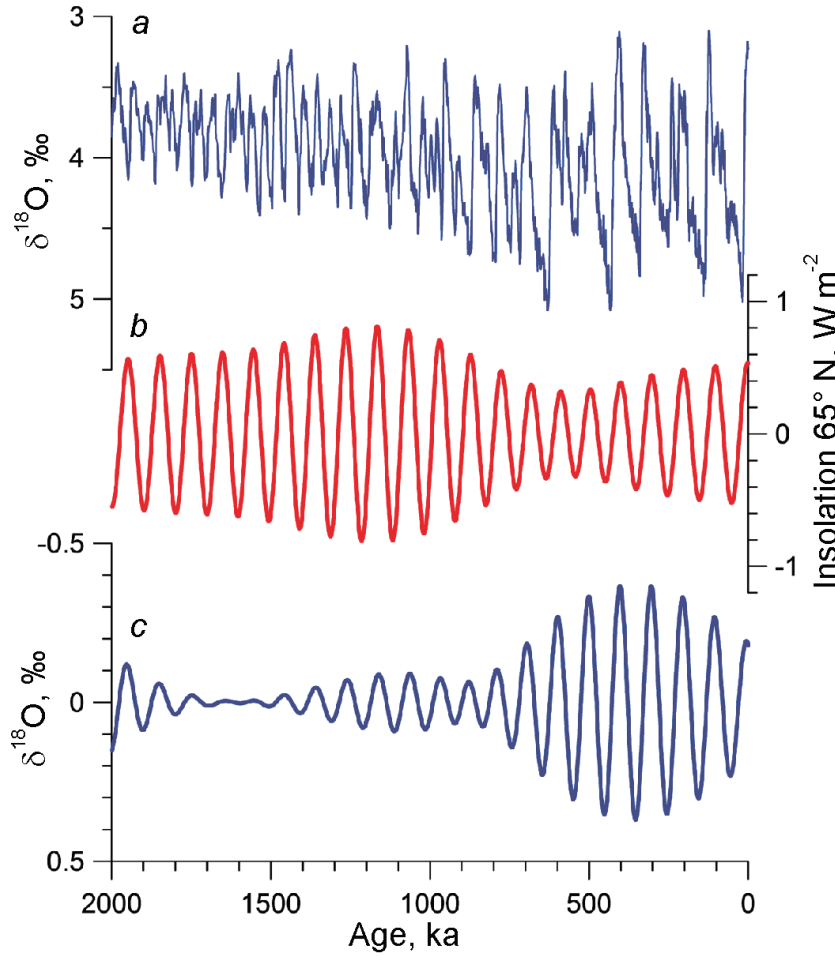

Fig. 2. Changes in insolation and benthic $\delta^{18} \mathrm{O}$ over the past two million years:

$a$ - the LR04 stack of benthic $\delta^{18} \mathrm{O}$ records [20] over the last $2 \mathrm{Ma} ; b$ - time series of June 21 insolation at $65^{\circ} \mathrm{N}$ [14] filtered using a 100-ka Gaussian filter with a bandwidth of $10 \mathrm{ka} ; b-$ the LR04 stack filtered using a 100-ka Gaussian filter with a bandwidth of $10 \mathrm{ka}$.

Calculations are performed with the Analyseries software [28]

Рис. 2. Изменение инсоляции и изотопного $\left(\delta^{18} \mathrm{O}\right)$ состава бентосных фораминифер за последние 2 млн лет: $a-$ сводный ряд LR04 данных по $\delta^{18} \mathrm{O}$ бентосных фораминифер [20] за последние 2 млн лет; $b$ - ряд инсоляции 21 июня, рассчитанный для параллели $65^{\circ}$ с.ш. [14] и сглаженный фильтром Гаусса 100 тыс. лет с полосой пропускания 10 тыс. лет; $c$ - сводный ряд LR04, сглаженный фильтром Гаусса 100 тыс. лет с полосой пропускания 10 тыс. лет.

Расчёты выполнялись с помощью программы Analyseries [28]

system to simulate, within the framework of the astronomical theory, the onset of a prominent $100 \mathrm{ka}$ cycle at the time of the MPT, by adding a long-term drift reflecting the cooling since the Miocene.

Most hypotheses for the origin of the MPT invoke a response to a long-term cooling possibly induced by decreasing atmospheric $\mathrm{CO}_{2}$ concentrations (see [6] and references herein). Raymo et al. [33] argued that pre-MPT predominance of the obliquity frequency is due to the cancellation effect of the integrated precession signal associated with changes in ice sheet volume, which is out of phase between the northern and southern hemispheres. They speculated that during MPT, high latitudes became cool enough to enable the growing Antarctic ice sheet to cover the terrestrial margin no longer vulnerable to ice melting. The consequence would have been that the Antarctic ice volume was controlled by sea level changes essentially driven by Northern Hemisphere ice sheet fluctuations, leading to inphase changes of northern and southern ice sheets. This would have strengthened the precession signal of the global $\delta^{18} \mathrm{O}$ marine record, and so induced a change in the observed predominant periodicity. The proposal that at the MPT, marine-based ice sheet margins replaced terrestrial margins around Antarctica, has been borne out by drill records from the margins of Antarctica on the edge of the Ross Sea [25, 26] and by ice-sheet-ice shelf model simulation of the dynamics of West Antarctica [32]. Further evidence for the major role of Antarctic ice volume during the MPT arises from a deep-ocean sediment core (ODP 1123) taken east from New Zealand. By separating the effects of ocean temperature and ice volume on the benthic oxygen isotopic record, Elderfield et al. [8] suggest that an abrupt increase in Antarctic ice volume initiated the MPT around $900 \mathrm{ka}$ ago.

\section{MPT and atmospheric $\mathrm{CO}_{2}$}

Assuming that the Pliocene cooling played a major role in the establishment of the MPT, we have yet to assess the potential contribution of atmospheric $\mathrm{CO}_{2}$ to this cooling trend and to the MPT shift between obliquity and eccentricity as the dominant orbital signal in the paleo-record.

Ice core record. The most direct and reliable archives of long-term atmospheric $\mathrm{CO}_{2}$ background level during the past are enclosed in Antarctic ice [34, 35]. The Vostok [31] and EPICA DC [21] ice cores offer the best $\mathrm{CO}_{2}$ record covering the last $800 \mathrm{ka}$. The record is, on the whole, remarkably correlated with the climate record imprinted in the same cores under the signature of the ice isotopic $\mathrm{D} / \mathrm{H}$ record $[13,31]$ and exhibits a dominant $\sim 100$ ka periodicity in the spectrum of the Earth motion driven by its orbital and axial oscillations. Unfortunately no other long vertical ice core offers, up to date, a continuous chronological sequence reaching $1 \mathrm{Ma}$ or more, and this is one of the major challenges in ice core science for the future [10]. 
There is another way to recover very ancient ice in Antarctica: by sampling a zone of blue ice at or near the surface. This ice, which has travelled a long way in depth, now appears at the surface in regions where no snow accumulates because of the winds and where ablation may occur due to radiative sublimation. Of course, the stratigraphy of this ice may have been disturbed because of its journey in depth and close to the bedrock, but it may be very old. Recently, Higgins et al. [11] reported on atmospheric composition, including $\mathrm{CO}_{2}, 1$ million years ago from blue ice in the Allan Hills in Antarctica. The estimated $1 \mathrm{Ma}$ ice, dated by the ${ }^{40} \mathrm{Ar}$ method with an uncertainty of about $\pm 200 \mathrm{ka}$, was found in a stratigraphically disturbed section at the base of a $126 \mathrm{~m}$ ice core. The $\mathrm{CO}_{2}$ concentrations measured on the $1 \mathrm{Ma}$ ice are in the range 221-277 ppm. They have to be compared with the $280 \mathrm{ppm}$ pre-industrial value and the glacial-interglacial oscillations over the last $800 \mathrm{ka}$, whose amplitudes are between about 170 and 300 ppm [21].

Marine record. In 2009, motivated by the lack of an ice core record of atmospheric $\mathrm{CO}_{2}$ covering the MPT period, Hönisch et al. [12] proposed using the boron isotopic composition in planktonic foraminifer, which is a proxy for past sea water $\mathrm{pH}$, to estimate atmospheric partial pressure of $\mathrm{CO}_{2}$ across the MPT. Based on this study, which presents a record back to $2 \mathrm{Ma}$, the pre-MPT atmospheric partial pressure of $\mathrm{CO}_{2}$ during interglacials were similar as during the recent post-MPT (the last $500 \mathrm{ka}$ ), whereas atmospheric $\mathrm{CO}_{2}$ during the pre-MPT glacial periods was higher than during post-MPT.

More recently [24], the boron-isotope record has been extended to the late Pliocene (3.3 to $2.3 \mathrm{Ma}$ ago), a period, which is supposed to include the warmest intervals of the Pliocene between 3.3 and $3 \mathrm{Ma}$ ago. This new record indicates atmospheric $\mathrm{CO}_{2}$ concentrations on the whole between 400 and $300 \mathrm{ppm}$.

In summary. The first attempt to get atmospheric $\mathrm{CO}_{2}$ levels around $1 \mathrm{Ma}$ ago from Antarctic blue ice indicates values between 221 and 277 ppm, i.e. below the pre-industrial level. This preliminary work reinforces the hope to get an accurate record from ice across the MPT in future. On the other hand, the marine Boron-isotope record has the potential to extend the record back to the Miocene. Combining the 2 records should help to assess the role of atmospheric $\mathrm{CO}_{2}$ in driving the long trend cooling during the Pleistocene and the MPT shift in the dominant orbital signal, which is observed in the paleorecord.

\section{The bottom section of the Vostok meteoric ice}

The next question to be discussed in this section is: could the oldest meteoric ice bedded at Vostok below $3345 \mathrm{~m}$, which has experienced severe deformation, folding, intermixing and diffusive smoothing, nevertheless still be useful in deciphering some of the aspects of the MPT enigma? The precondition for a positive answer is that the disturbed ice should be much older than the undisturbed section of the Vostok ice core (420 ka) and older than the oldest continuous EPICA record obtained so far, which spans back to $800 \mathrm{ka}$ [9]. In that case, despite the stratigraphic discontinuity, studies of such ice, in particular the measurements of the air content and the concentration of $\mathrm{CO}_{2}$ in trapped air, can yield new important information on the potential role of the Antarctic ice sheet instability and the atmospheric carbon dioxide in the genesis of MPT. Below we present and discuss some old and new data on the ice texture and fabric, the air content of ice and the geometrical properties of the air-hydrate crystals obtained from the Vostok ice core below $3310 \mathrm{~m}$, which in our view should stimulate further comprehensive investigations of the $228 \mathrm{~m}$ thick stratum of disturbed meteoric ice at Vostok.

Ice texture and fabric. In the Vostok core of meteoric ice, two different types of microstructure, referred to as A and B, distinguish interglacial ice from glacial ice $[2,18]$. In the A layers, which have low impurity content of ice and are associated with interglacial conditions, the ice grains are larger and their $c$-axes exhibit vertical-girdle-type orientation. Stress field leading to such fabric is characterised by uniaxial tension in the direction of the ice flow. As a result, $c$-axes rotate away from the tensile axis, which makes the ice harder to deform.

On the contrary, in the B layers, which have been formed under conditions of glacial maxima and are therefore characterised by high impurity content, the fine-grained ice with vertical clustering of $c$-axes is observed. This kind of fabric pattern corresponds to vertical compression in the upper part of ice sheet, or to simple shear in its bottom part.

The difference between the two types of layers, being very small in the upper section of the ice sheet, 


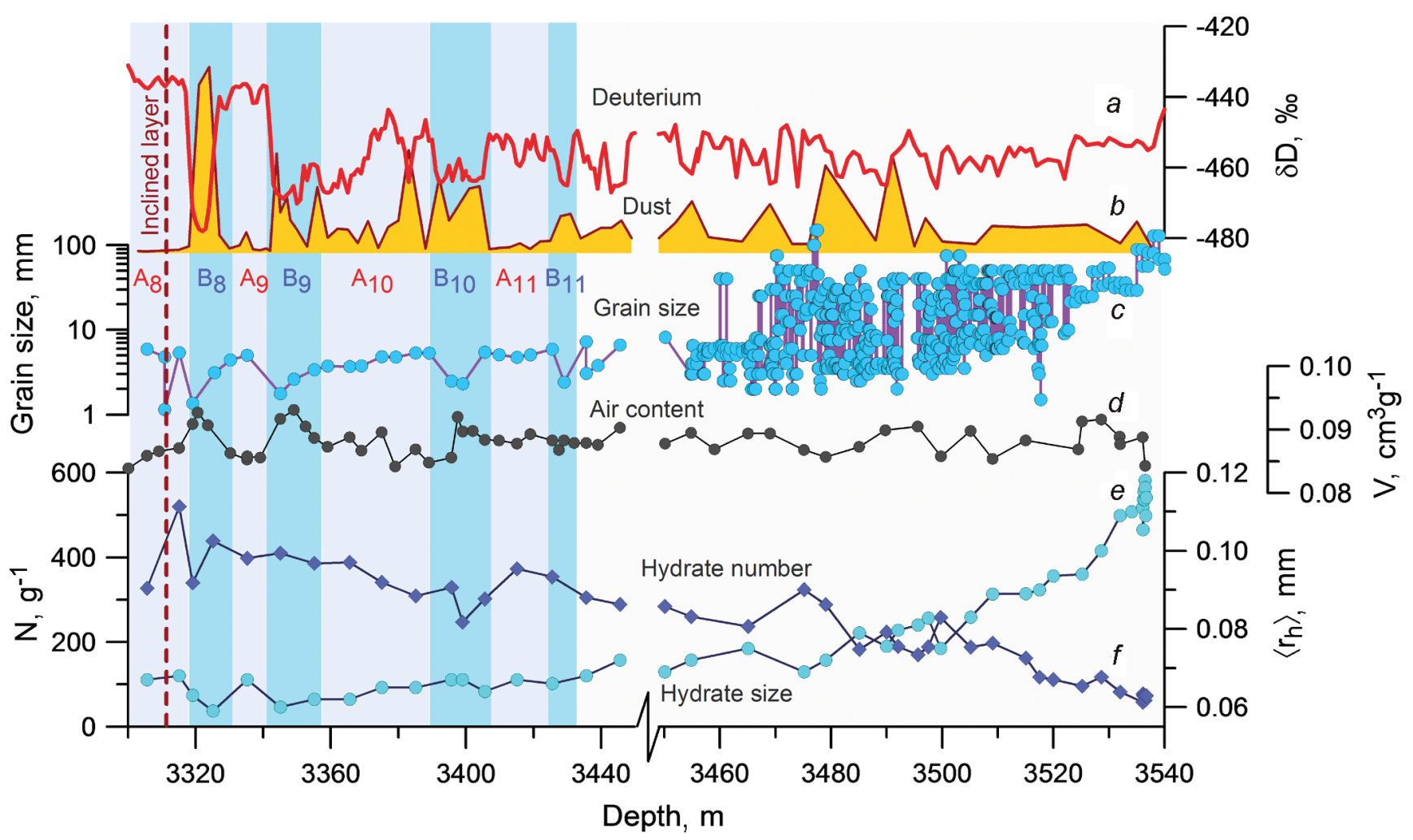

Fig. 3. Physical and geochemical properties of the Vostok meteoric ice bedded between $3310 \mathrm{~m}$ and $3539 \mathrm{~m}$ below the surface: $a$-deuterium content of the ice $\delta \mathrm{D}, \% \circ[31,40] ; b-$ the atmospheric dust concentration [31, 39] (axis is not shown); $c-$ size of ice grains, $\mathrm{mm}$ [2, this work]; $d$ - air content of ice $V, \mathrm{~cm}^{3} \mathrm{~g}^{-1} ; e-$ mean radius of air-hydrate crystals $\left\langle r_{h}\right\rangle$, mm [3, this work]; $f-$ number concentration of air-hydrate crystals $N, \mathrm{~g}^{-1}$ [3, this work].

Layers A8-A11 consist of coarse-grained ice with vertical-girdle fabric; they were deposited at the interglacial conditions. Layers B8B11 have fine-grained texture and preferable vertical (single-maximum) orientation of $c$-axes; they were deposited at the glacial conditions. Below $3450 \mathrm{~m}$, the thickness of these layers reduces to a centimeter scale. Three thin volcanic ash layers inclined in opposite directions were observed at a depth of $3311 \mathrm{~m}$. They are believed to mark the upper boundary of the disturbed ice at Vostok [31]

Рис. 3. Физические и геохимические характеристики атмосферного льда, залегающего в районе станции Восток в интервале глубин 3310-3539 м:

$a-$ содержание дейтерия во льду $\delta \mathrm{D}, \%$ [31, 40]; $b$ - концентрация атмосферной пыли [31, 39] (шкала не показана); $c$ размер зёрен льда, мм [2, эта работа]; $d$ - общее газосодержание ледяной породы $V$, см$^{3} \Gamma^{-1} ; e-$ средний радиус кристаллов гидратов воздуха $\left\langle r_{h}\right\rangle$, мм [3, эта работа]; $f$ - счётная концентрация кристаллов гидратов воздуха $N, \mathrm{~g}^{-1}[3$, эта работа]. Слои А8-А11 сложены крупнокристаллическим льдом с поясной ориентировкой $c$-осей кристаллов; эти слои сформировались в условиях межледниковых периодов. Слои В8-В11 сложены мелкокристаллическим льдом с одномаксимумной ориентировкой $c$-осей; эти слои формировались в условиях ледниковых максимумов. Глубже 3450 м мощность слоёв с различным строением льда уменьшается до нескольких сантиметров. Три тонких прослоя вулканической пыли с несогласным залеганием обнаружены на глубине 3311 м. Считается, что глубже этого горизонта стратиграфическая последовательность залегания ледяных слоёв нарушена [31]

increases with depth, as shear stress become progressively more important, and, finally, clearly manifests itself in the disturbed section of meteoric ice below $3310 \mathrm{~m}$ (see Fig. 1 and Fig. 3). Two distinct strata can be easily discerned here. Between 3310 and $3460 \mathrm{~m}$, the relatively long-wave variations in the ice textural and fabric properties (see layers A8-A11 and B8B11 in Fig. 3) occur in concordance with climatic changes reflected in the isotopic (see Fig. 3, $a$ ) and dust (see Fig. 3, b) contents of the ice, in a similar way as has been documented for the undisturbed section of meteoric ice above $3310 \mathrm{~m}$. However, it has been proposed [41] and later on confirmed experimentally (for depth interval of 3320-3345 m) [36] that a large-scale folding, at a scale of a few tens of meters, could have altered the original stratigraphic sequence in this part of the Vostok core. The observed dumping of variations in the isotopic composition and the impurity content (see Fig, 3,a,b) is considered to be a result of ice mixing, which should 
accompany the large-scale ice folding [40, 41]. The latter inference is supported by three thin ash layers slipping in opposite directions, which have been discovered at an interval of a few centimeters, at depths of 3310.6 and $3310.8 \mathrm{~m} \mathrm{[31].}$

Below $3460 \mathrm{~m}$, a scale of the A- and B layers interbedding is reduced to the $10^{-2}-10^{-1} \mathrm{~m}$. At the same time, the amplitude of the grain size variations increases by an order of magnitude, mostly due to the abnormal grain growth at annealing temperatures, uninhibited by insoluble impurities in the A layers. The ice fabric pattern remains the same here as in the upper section of the disturbed ice, that is the girdle-type $c$-axis orientation is observed in the A layers with low concentration of atmospheric dust, and the single-maximum fabric in the B layers with high dust concentration (see Fig. 5 in [39]). However, the diffusive smoothing superimposed on the ice mixing at submetric scale would normally have drastically altered the isotopic signal. Consequently, high-resolution isotope measurements, which have been performed continuously along the selected depth intervals, do not reveal coherent variations with the dust and textural properties of A and B layers (A. Ekaykin, unpublished data). Importantly, the air-hydrate crystals exhibit uninterrupted gradual growth with depth (age) of ice in the bottom section of the Vostok core (see below). This has been regarded as a proof that only centimeter scale intermixing of ice, if any, could have taken place here [18].

At the very bottom of meteoric ice, between 3522 and $3539 \mathrm{~m}$, the amplitude of the grain size variations significantly decreases (see Fig. 3,c), apparently due to the sudden disappearance of the B type layers. This could result from the uniformly low concentration of dust below $3522 \mathrm{~m}$, although more dust measurements are needed to prove this assertion (see available data in Fig. 3, b).

Folding and the ice flow disturbance in the bottom $\sim 250 \mathrm{~m}$ of glacier ice are well known phenomena. It has been shown that the difference in the mechanical properties of layers with distinct microstructure, as those described above as layers A and $\mathrm{B}$, may cause micro-folding at a scale of a few centimeters [7]. Assuming a longitudinal compression of ice would lead to a concept of tectonic thickening and progressive build-up of the deformed basal ice upwards with more advanced deformation close to the bed [41]. Such stress conditions indeed may occur in the vicinity of Vostok Station, at the south- ern end of Lake Vostok. Here the ice sheet is substantially grounded, so that the lake edge, which is located less than $5 \mathrm{~km}$ downstream from the borehole, can hinder the basal ice movement and favour ice blocking [18]. The existence of a «young» (present-day) shear zone beneath Vostok appears to be the most plausible explanation for the highly deformed ice observed in the deepest section of the disturbed ice (3460-3539 m). Indeed, if such a zone was generated upstream from Lake Vostok, all textural and fabric distinction between layers A and B would have been eliminated by the ice recrystallisation under annealing temperatures $\left(4.5-6^{\circ}\right.$ below the pressure melting point) during the long ( $40 \mathrm{kyr}$ [38]) journey of this ice over subglacial Lake Vostok, from the upstream grounding line to the drilling site.

On the contrary, the large scale folding, which is presumed to be characteristic of the upper, cooler section of the disturbed ice, between 3310 and $3460 \mathrm{~m}$ (though up to now it has only been confirmed on one occasion, in the depth interval of $3320-3345 \mathrm{~m}$ ), is thought to have occurred when the ice was grounded upstream from Vostok, due to the interaction of the basal ice with the bedrock undulations. Earlier studies have shown that the freezing of lake water on the sole of the ice sheet in the area of Vostok Station occurred as soon as the ice crossed the grounding line $[38,41]$. This implies that the basal ice did not experience loss by melting after contact with the lake water, and that very old, though badly deformed, Antarctic ice may exist here.

Air content of ice. We have measured the air content of ice $(V)$ along the disturbed section of the Vostok ice core using a barometric method implemented with an experimental setup called STAN [17]. The absolute precision of the STAN measurements is estimated to be within $\pm 0.6 \%$ for typical for polar ice level of air content of an order of $0.1 \mathrm{~cm}^{3} \mathrm{~g}^{-1}$ (hereafter the gas volume is given at standard conditions: $T=273.15 \mathrm{~K}$ and $P=0.1013 \mathrm{MPa})$. The new data presented in Fig. 3, $d$ extends the previously obtained Vostok $V$ records $[19,22]$ to the boundary between the meteoric ice and accreted ice at $3539 \mathrm{~m}$ below the surface. The whole combined $V$ record (not shown) demonstrates a weak tendency of air content to decrease with increasing depth. The mean values of $V$ were found to be $0.0892 \pm 0.0037 \mathrm{~cm}^{3} \mathrm{~g}^{-1}( \pm 10 \sigma)$ between 114 and $3310 \mathrm{~m}$ (i.e. during the last $\sim 420 \mathrm{ka}$ ), $0.0884 \pm 0.0021 \mathrm{~cm}^{3} \mathrm{~g}^{-1}$ in the depth interval of 3310 $3500 \mathrm{~m}$, and $0.0881 \pm 0.0022 \mathrm{~cm}^{3} \mathrm{~g}^{-1}$ below $3500 \mathrm{~m}$. 


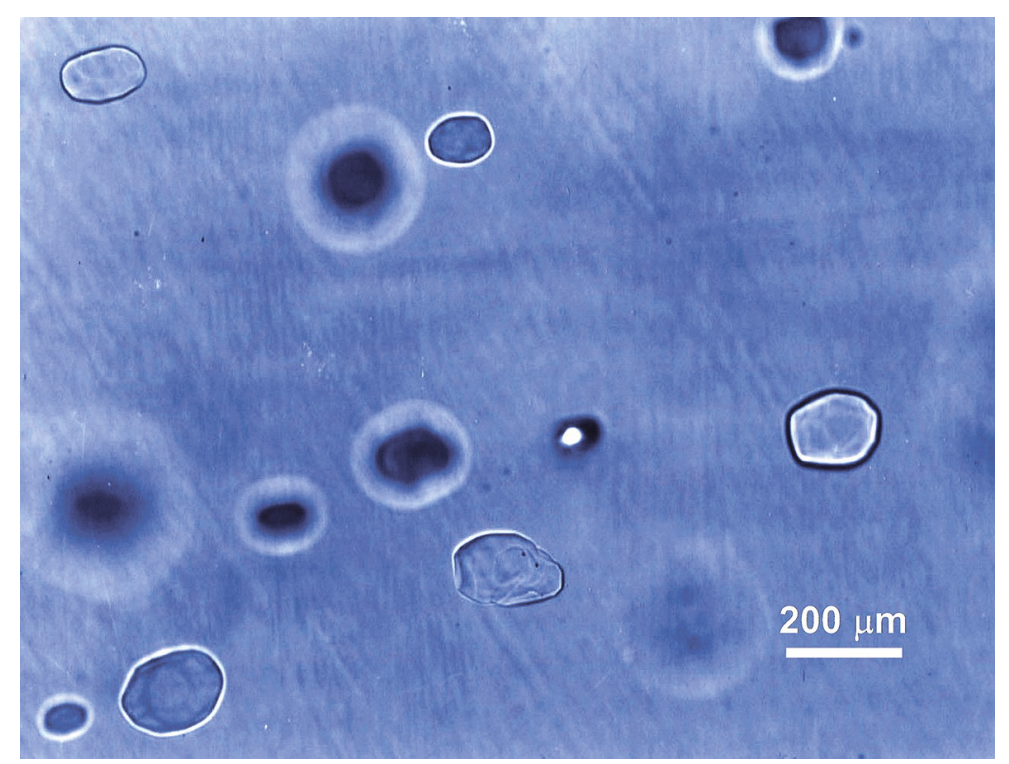

Fig. 4. Ensemble of mixed air clathrate-hydrate crystalline inclusions in the old Vostok meteoric ice from a depth of $3535 \mathrm{~m}$

Рис. 4. Ансамбль кристаллических включений смешанных клатратных гидратов воздуха в керне атмосферного льда станции Восток с глубины 3535 м

The air content of polar ice averaged over the time spans covering several climatic cycles should be proportional to the mean atmospheric pressure at the site of the ice formation (see e.g. [23]). For instance, the observed decrease of the $V$ in the deeper sections of the Vostok ice core reflects advection of ice from the sites with higher elevation, located upstream from Vostok. Aside from this trend, the new measurements show that the mean air content of the oldest meteoric ice is almost the same as that measured in the upper section of the Vostok core (114-3310 m) [19, 22], and in other words, typical for polar ice formed at the conditions (atmospheric pressure, temperature) prevailing at Vostok Station [23]. This implies that during a long time period covering the formation of the presently $3539 \mathrm{~m}$ thick stratum of meteoric ice at Vostok, the ice-sheet surface elevation in this part of Antarctica has been essentially stable and similar to that during the last $420 \mathrm{ka}$.

Growth of air-hydrate crystals and the maximum age of meteoric ice at Vostok. Dating the disturbed ice is the key challenge. Provided the basal ice flow has not been disturbed, extrapolation of the existing glaciological timescales below the end of the continuous climatic record at Vostok can give a conditional estimate of the age-depth relationship for meteoric ice bedded below a depth of $3310 \mathrm{~m}$. With different assumptions about temperature and accumulation rate prior to $420 \mathrm{ka} \mathrm{BP}$, the boundary conditions along the Vostok flow line, and available independent constraints on the ice flow modeling and ice dating, the glaciological models estimate the age of ice at a depth of $3500 \mathrm{~m}$ to be between 716 and $930 \mathrm{ka}[30,38]$.

Another approach to dating very old glacier ice employs the post-formation growth («Ostwald ripening») of mixed air clathrate-hydrate crystals (Fig. 4), which occurs in the polar ice sheet due to diffusion of air molecules through the ice matrix. The difference in size between crystals induces the gas-concentration gradients in the ice matrix and creates a driving force for oxygen and nitrogen diffusion from smaller crystals towards the larger ones. Based on the theory of precipitation from supersaturated solutions [15], A. Salamatin with co-authors [37] have developed a mathematical description of this process. Their model describes the time evolution of the hydrate-size distribution below the bubble-to-hydrate transition zone.

The size and number concentration, $N$, of air hydrates have been measured in thin section of ice under a binocular microscope, using experimental and calculation procedures elaborated for the Vostok ice core [16]. In accordance with the model prediction, the data show a sharp increase in the mean radius of hydrates, $\left\langle r_{h}\right\rangle$, and corresponding decrease in $N$ within the lowest 40 meters of the meteoric ice, 
in close proximity to its boundary with ice accreted from Lake Vostok's water (see Fig. 3, $e, f$ ). It is worth noting that the volume concentration of hydrates (as well as the mean air content of ice) in the disturbed ice between 3310 and $3539 \mathrm{~m}$ remain at the same levels as in the upper section of the Vostok core covering the last four climatic cycles.

Numerous computational experiments performed with the model of hydrate ripening [37] and an improved thermo-mechanical model simulating the ice flow and the heat transfer along the fixed flow tube passing through Vostok Station [38], has shown that the climatically induced fluctuations in the airhydrate geometrical properties [16] become essentially extinguished below $3400 \mathrm{~m}$ and that the mean radius of the inclusions increases linearly with the age of the ice between 3100 and $3500 \mathrm{~m}$ [3]. This inference has been used to extend the extrapolated glaciological timescale [38] from $3500 \mathrm{~m}$ down to the interface between meteoric and accreted ices using experimental data on the size of air hydrates. Using this procedure, the maximum age of the meteoric ice beneath Vostok was calculated to be $1.85 \pm 0.2 \mathrm{Ma}$ [3].

\section{Summary and outlook}

The ice flow disturbances, which alter the stratigraphic continuity and mask the paleoclimatic record in the Vostok ice core below $3310 \mathrm{~m}$, occur on a relatively small scale and do not disguise the expected growth of air-hydrate crystals with depth (age of ice) at the annealing conditions prevailing in the bottom part of the ice sheet. This has allowed the first assessment of the maximum age of the disturbed ice to be carried out on the basis of the hydrate growth experimental data and theory. The preliminary results seem to be encouraging, since they indicate that potentially, Antarctic ice older than 1.5 Ma is present in the existing Vostok ice core. The air content measured in the deepest section of the core suggests that the surface elevation in the central part of the East Antarctic ice sheet has been stable over the time span corresponding to the period of meteoric ice accumulation ( $>1.5 \mathrm{Ma}$ ?), thus supporting the current model results [32].

The results obtained at this stage of the studies impel us to propose further comprehensive investigations in order to meet the Vostok Oldest Ice Challenge more closely. We therefore suggest the following next steps within the VOICE project.
1. Ice dating and chronology reconstruction. This theme includes further refinement of the ice dating method based on the air-hydrate crystal growth data and theory. The uncertainties of this approach should be more carefully assessed. A number of new absolute methods for old ice dating are currently under development. Taking into account the limited amount of ice available for analysis, it is most feasible that only ${ }^{40} \mathrm{Ar} /{ }^{38} \mathrm{Ar} \mathrm{[5]}$ and ${ }^{26} \mathrm{Al} /{ }^{10} \mathrm{Be}$ [4] dating techniques can be applied to obtain independent age estimates for the oldest meteoric ice at Vostok. Reconciliation of the results would help to clarify the uncertainties of the different dating methods used, and would be crucial for the overall progress of the VOICE project. One can also envisage that the age of the Vostok disturbed ice younger than 800 ka may be reconstructed through the matching of globallyhomogeneous atmospheric parameters $\left(\delta^{18} \mathrm{O}, \mathrm{CO}_{2}\right.$, $\mathrm{CH}_{4}$ ) measured in the Vostok core to those in the dated EPICA ice core records. New, additional gas measurements on the Vostok ice core are necessary to allow such matching.

2. $\mathrm{CO}_{2}$ measurements. If the very old age of Vostok meteoric ice, as inferred from the air-hydrate growth below $3500 \mathrm{~m}$, is confirmed, the measurements of concentration of carbon dioxide in the air extracted from this ice will allow us to extend the Antarctic ice record of $\mathrm{CO}_{2}$ beyond $1 \mathrm{Ma} \mathrm{BP}$.

3. High-resolution stable isotope measurements. The existing isotopic record for the deepest section of the Vostok meteoric ice (see Fig. 3,a) was measured continuously on 1-m long samples. It is advisable to perform new measurements with a resolution of $0.1 \mathrm{~m}$ or better in order to obtain data which could be useful for studying relative contributions of the small-scale ice mixing and diffusive smoothing of the isotopic signal to the observed dumping of the isotope record below $3350 \mathrm{~m}$. Depending on the progress of this study, the Vostok isotopic record can be deconvolved and matched to the appropriately scaled EPICA record in the age interval between 800 and $400 \mathrm{ka}$ BP. This would help to reconstruct the ice chronology in the upper section of the disturbed ice, between 3345 and $3460 \mathrm{~m}$.

4. High-resolution studies of ice microstructure (texture, fabric and imperfection of ice crystals). Such studies, if performed on a continuous basis in the depths interval of 3460-3539 m, may yield valuable information related to the formation of the shear zone and of the submetric-scale ice mixing at the 
base of meteoric ice at Vostok. High-resolution measurements of dust concentration in selected depth intervals would be of use for interpreting the microstructural data. Aside from this, the microstructural properties may help to distinguish between interglacial ice and glacial ice layers in the conditions when even a high-resolution isotopic profile becomes noninformative in this respect. This may be in demand when interpreting the data from gas analyses, which are planned for this section of the core.

The additional measurements proposed above will require a considerable amount of ice, especially in the case of the ${ }^{40} \mathrm{Ar} /{ }^{38} \mathrm{~A}$ and ${ }^{26} \mathrm{Al} /{ }^{10} \mathrm{Be}$ analyses. The replicate ice core from borehole $5 \mathrm{G}-3$ recently obtained at Vostok Station, which duplicates the old 5G-1 core between 3458 and $3538 \mathrm{~m}$, will allow implementation of the planned measurement, and revalidation of obtained results, if needed, as well.

5. Reconnaissance studies along the Vostok flow line, and in the vicinity of Ridge B. Although the continuous paleoclimatic record is hardly available from the Vostok ice below $3310 \mathrm{~m}$, there is potential for recovering a longer, continuous paleoclimatic record at a site located upstream of Vostok, in the vicinity of Ridge B. Detailed geophysical and glaciological surveys in this region, accompanied by modeling efforts, as recommended by the IPICS community [10], should be part of the VOICE project.

In our view, implementing the VOICE project in accordance with the proposed plan will significantly boost our understanding as to how and to what extent the oldest Antarctic ice may help in deciphering the enigma of the Mid-Pleistocene climatic transition. The methodological developments and the expertise associated with progress in VOICE could be useful for future studies of the new oldest ice core, which is anticipated from the new deep drilling project in East Antarctica recently proposed by the international ice core community, represented by the International Partnership for Ice Core Science - IPICS (http:// www.pages-igbp.org/ini/end-aff/ipics/intro).

Acknowledgements. This work was financially supported by the Russian Science Foundation, grant 14-27-00030. The collaborative research was carried out in the network of the Russian-French International Associated Laboratory (LIA) «Climates and Environments from Ice Archives». We are grateful to A. Salamatin, F. Parrenin, C. Ritz, M-F. Loutre, D. Paillard, D. Pollard and A. Ekaykin for useful discussions. We also thank A. Lagnado for English editing of the manuscript.

\section{References}

1. Екайкин А.А., Козачек А.В., Липенков В.Я., Преображенская А.В., Шибаев Ю.А. Гидрологический режим подледникового озера Восток (Антарктида) по данным геохимических исследований ледяного керна и озерной воды // Вестн. РФФИ. 2013. № 2 (78). C. 57-63.

2. Липенков В.Я., Полякова Е.В., Дюваль П., Преображенская A.B. Особенности строения антарктического ледникового покрова в районе станции Восток по результатам петроструктурных исследований ледяного керна // Проблемы Арктики и Антарктики. 2007. № 76. С. 68-77.

3. Цыганова Е.А., Липенков В.Я. Рост воздушных гидратов и возраст придонного льда в Центральной Антарктиде // Лёд и Снег. 2011. № 1 (113). C. 5-12.

4. Auer M., Wagenbach D., Wild E.M., Wallner A., Priller A., Miller H., Schlosser C., Walter K. Cosmogenic ${ }^{26} \mathrm{Al}$ in the atmosphere and the prospect of a ${ }^{26} \mathrm{Al} /{ }^{10} \mathrm{Be}$ chronometer to date old ice // Earth and Planetary Science Letters. 2009. V. 287. P. 453-462.

5. Bender M.L., Barnett B., Dreyfus G., Jouzel J., Porcelli $D$. The contemporary degassing rate of ${ }^{40} \mathrm{Ar}$ from the solid Earth // PNAS. 2008. V. 105 (24). P. 8232-8237.

6. Clark P.U., Archer D., Pollard D., Blum J.D., Rial J., Brovkin V., Mix A.C., Pisias N.G., Roy M. The middle Pleistocene transition: characteristics, mechanisms, and implications for long-term changes in atmospheric $\mathrm{pCO}_{2} / /$ Quaternary Science Reviews. 2006. doi:10.1016/j.quascirev.2006.07.008.

7. Dahl-Jensen D., Thorsteinsson T., Alley R., Shoji H. Flow properties of the ice from the Greenland Ice Core Project ice core: the reason for folds? // Journ. of Geophys. Research. 1994. V. 102. N C12. P. 26831-26840.

8. Elderfield H., Ferretti P., Greaves M., Crowhurst S., McCave I.N., Hodell D., Pioytroski A.M. Evolution of ocean temperature and ice volume through the MidPleistocene Climate Transition // Science. 2012. V. 337. P. 704-709.

9. EPICA community members. Eight glacial cycles from an Antarctic ice core // Nature. 2004. V. 429. P. 623-628.

10. Fischer H., Severinghaus J., Brook E., Wolff E., Albert M., Alemany O., Arthern R., Bentley C., Blankenship D., Chappellaz J., Creyts T., Dahl-Jensen D., Dinn M., Frezzotti M., Fujita S., Gallee H., Hindmarsh R., Hudspeth D., Jugie G., Kawamura K., Lipenkov V., Miller H., Mulvaney R., Parrenin F., Pattyn F., Ritz C., Schwander J., Steinhage D., van Ommen T., 
Wilhelms $F$. Where to find 1.5 million yr old ice for the IPICS «Oldest-Ice» ice core // Climate of the Past. 2013. V. 9. P. 2489-2505.

11. Higgins JA., Kurbatov AV., Spaulding NE., Brook E., Introne DS., Chimiak LM, Yan Y., Mayewski P.A., Bender M.L. Atmospheric composition 1 million years ago from blue ice in the Allan Hills, Antarctica // PNAS. 2015. V. 112 (22). P. 6887-6891.

12. Hönisch B., Hemming NG., Archer D., Siddall M., McManus JF. Atmospheric Carbon Dioxide Concentration Across the Mid-Pleistocene Transition // Science. 2009. V. 324. P. 1551-1554.

13. Jouzel J., Masson-Delmotte V., Cattani O., Dreyfus G., Falourd S., Hoffmann G., Minster B., Nouet J., Barnola J.M., Chappellaz J., Fischer H., Gallet J.C., Johnsen S., Leuenberger M., Loulergue L., Luethi D., Oerter H., Parrenin F., Raisbeck G., Raynaud D., Schil A., Schwander J., Selmo E., Souchez R., Spahni R., Stauffer B., Steffensen J.P., Stenni B., Stocker T.F., Tison J.L., Werner M., Wolff E.W. Orbital and millennial Antarctic climate variability over the past 800,000 years // Science. 2007. V. 317. P. 793-796.

14. Laskar J., Robutel P., Joutel F., Gastineau M., Correia A.C.M., Levrard B. A long-term numerical solution for the insolation quantities of the Earth // Astronomy \& Astrophysics. 2004. V. 428. P. 261-285. doi:10.1051/0004-6361:20041335.

15. Lifshitz I.M., Slyozov V.V. The kinetics of precipitation from supersaturated solid solutions // Journ. of Phys. Chem. Solids. 1961. V. 19 (1/2). P. 35-50.

16. Lipenkov V.Ya. Air bubbles and air-hydrate crystals in the Vostok ice core // In: T. Hondoh, ed. Physics of ice core records. Sapporo: Hokkaido University Press, 2000. P. 327-358.

17. Lipenkov V., Candaudap F., Ravoire J., Dulac E., Raynaud $D$. A new device for air content measurements in polar ice // Journ. of Glaciology. 1995. V. 41 (138). P. 423-429.

18. Lipenkov V.Ya., Barkov N.I. Internal structure of the Antarctic Ice Sheet as revealed by deep core drilling at Vostok Station // Lake Vostok Study: Scientific Objectives and Technological Requirements: International Workshop. March 24-26 1998. St. Petersburg, AARI, 1998. P. 31-35.

19. Lipenkov V.Ya., Raynaud D., Loutre M.F., Duval P. On the potential of coupling air content and $\mathrm{O}_{2} / \mathrm{N}_{2}$ from trapped air for establishing an ice core chronology tuned on local insolation // Quaternary Science Reviews. 2011. V. 30. P. 3280-3289. doi:10.1016/j.quascirev.2011.07.013.

20. Lisiecki L.E., Raymo M.E. A Pliocene-Pleistocene stack of 57 globally distributed benthic $\partial 180$ records // Paleoceanography. 2005. V. 20. PA1003. doi:10.29/2004PA001071.

21. Lüthi D., Le Floch M., Bereiter B., Blunier T., Barnola J.-M., Siegenthaler U., Raynaud D., Jouzel J., Fisch- er H., Kawamura K., Stocker T.F. High-resolution carbon dioxide concentration record 650,000-800,000 years before present // Nature. 2008. V. 453. P. 379-382.

22. Martinerie P., Lipenkov V.Ya., Raynaud D., Chappellaz J., Barkov N.I., Lorius C. Air content paleo record in the Vostok ice core (Antarctica): A mixed record of climatic and glaciological parameters // Journ. of Geophys. Research. 1994. V. 99. № D5. P 10565-10576.

23. Martinerie P., Raynaud D., Etheridge D.M., Barnola J-M., Mazauder D. Physical and climatic parameters which influence the air content in polar ice // Earth and Planetary Science Letters. 1992. V. 112. P. 1-13.

24. Martinez-Boti M.A., Foster G.L., Chalk T.B., Rohling E.J., Sexton P.F., Lunt D.J., Pancost R.D., Badger M.P.S., Schmidt D.N. Plio-Pleistocene climate sensitivity evaluated using high-resolution $\mathrm{CO} 2$ records // Nature. 2015. V. 518. P. 49-54.

25. McKay R., Naish T., Powell R., Barrett P., Scherer R., Talarico F., Kyle P., Monien D., Kuhn G., Jackolski C., Williams T. Pleistocene variability of Antarctic Ice Sheet extent in the Ross Embayment // Quaternary Science Reviews. 2012. V. 34. P. 93-112.

26. Naish T., Powell R., Levy R., Wilson G., Scherer R., Talarico F., Krissek L., Niessen F., Pompilio M., Wilson T., Carter L., DeConto R., Huybers P., McKay R., Pollard D., J. Ross J., Winter D., Barrett P., Browne G., Cody R., Cowan E., Crampton J., Dunbar G., Dunbar N., Florindo N., Gebhardt C., Graham I., Hannah M., Hansaraj D., Harwood D., Helling D., Henrys S., Hinnov L., Kuhn G., Kyle P., Laufer A., Maffioli P., Magens D., Mandernack R., McIntosh W., Millan C., Morin R., Ohneiser C., Paulsen T., Persico D., Raine I., Reed J., Riesselman C., Sagnotti L., Schmitt D., Sjunneskog C., Strong P., Taviani M., Vogel S., Wilch T., Williams T. Obliquity-paced Pliocene West Antarctic ice sheet oscillations // Nature. 2009. V. 458. P. 322-328.

27. Paillard $D$. The timing of Pleistocene glaciations from a simple multiple-state climate model // Nature. 1998. V. 391. P. 378-381.

28. Paillard D., Labeyrie L., Yiou P. Macintosh program peforms time-series analysis // EOS Trans. AGU. 1996. № 77. P. 379.

29. Paillard D., Parrenin F. The Antarctic ice sheet and the triggering of deglaciations // Earth and Planetary Science Letters. 2004. V. 227. P. 263-271.

30. Parrenin F., Remy F., Ritz C., Siegert M.J., Jouzel J. New modeling of the Vostok ice flow line and implication for the glaciological chronology of the Vostok ice core // Journ. of Geophys. Research. 2004. V. 109. D20102. doi:10.1029/2004JD004561.

31. Petit J.R., Jouzel J., Raynaud D., Barkov N.I., Barnola J.M., Basile I., Bender M., Chappellaz J., Davis M., Delague G., Delmotte M., Kotlyakov V.M., Legrand M., Lipenkov V.Ya., Lorius C., Pepin L., Ritz C., 
Saltzman E., Stievenard M. Climate and atmospheric history of the past 420,000 years from the Vostok ice core, Antarctica // Nature. 1999. V. 399. № 6735. P. 429-436.

32. Pollard D., DeConto R.M. Modelling West Antarctic ice sheet growth and collapse through the past five million years // Nature. 2009. V. 458. P. 329-332.

33. Raymo M.E., Lisiecki L.E., Nisancioglu K.H. PlioPleistocene ice volume, Antarctic climate, and the global $\delta^{18} \mathrm{O}$ record // Science. 2006. V. 313. P. 492-495.

34. Raynaud $D$. The integrity of the ice record of greenhouse gases with a special focus on atmospheric $\mathrm{CO}_{2} / /$ Ice and Snow. 2012. V. 2 (118). P. 5-14.

35. Raynaud D., Jouzel J., Barnola J.M., Chappellaz J., Delmas R.J., Lorius $C$. The ice record of greenhouse gases // Science. 1993. V. 259. P. 926-934.

36. Raynaud D., Barnola J.M., Souchez R., Lorrain R., Petit J.R., Duval P., Lipenkov V.Ya. The record for marine isotopic stage $11 / /$ Nature. 2005. V. 436. P. 39-40.

37. Salamatin A.N., Lipenkov V.Ya., Hondoh T. Air-hydrate crystal growth in polar ice // Journ. of Crystal Growth. 2003. V. 257. P. 412-426.

38. Salamatin A.N., Tsyganova E.A., Popov S.V., Lipenkov V.Ya. Ice flow line modeling in ice core data interpretation: Vostok Station (East Antarctica) // In: Hondoh T., ed. Physics of ice core records. Sapporo: Hokkaido University Press, 2009. V. 2. P. 167-194.

39. Simoes J.C., Petit J.R., Souchez R., Lipenkov V.Ya., De Angelis M., Liu L., Jouzel J., Duval P. Evidence of glacial flour in the deepest $89 \mathrm{~m}$ of the glacier ice from Vostok core // Annals of Glaciology. 2002. V. 35. P. 340-346.

40. Souchez R., Jean-Baptiste P., Petit J.R., Lipenkov V. Ya., Jouzel J. What is the deepest part of the Vostok ice core telling us? // Earth-Science Review. 2002. V. 60. P. 131-146.

41. Souchez R., Petit J.R., Jouzel J., Simões J., de Angelis M., Barkov N., Stievenard M., Vimeux F., Sleewaegen $S$., Lorrain $R$. Highly deformed basal ice in the Vostok core, Antarctica // Geophys. Research Letters. 2002. V. 29. P. 4041-4044.

\section{Климатическая перестройка в середине плейстоцена и проблема исследования древнейшего льда со станции Восток}

Результаты исследований колонок морских донных осадков [20] показывают, что в середине плейстоцена, около 1 млн лет назад (л.н.), произошло изменение периодичности глобальных изменений климата: климатические колебания, связанные с чередованием ледниковых и меж- ледниковых эпох, которые до этого происходили с периодом около 40 тыс. лет, сменились более значительными по амплитуде колебаниями с периодом около 100 тыс. лет. Причины, вызвавшие перестройку климатической системы планеты (Mid Pleistocene Transition - MPT), пока не известны и приковывают к себе пристальное внимание климатологов.

Большинство гипотез связывают произошедшие тогда изменения с растянувшимся на многие сотни тысяч лет похолоданием климата планеты, которое, как считают многие исследователи, вызвано постепенным понижением концентрации $\mathrm{CO}_{2}$ в атмосфере Земли [6]. Это продолжительное похолодание могло не только вызвать разрастание (в более холодные эпохи) ледниковых щитов Северной Америки, но и привести к увеличению размеров Восточно-Антарктического ледникового покрова. Последнее сопровождалось продвижением края ледника в сторону моря и, следовательно, изменением механизма его реакции на колебания климатических условий и уровня Мирового океана [33]. Выяснение истинных причин МРТ станет существенным прогрессом в понимании роли углеродного цикла в глобальных климатических изменениях, что в свою очередь повысит надёжность долгосрочных и сверхдолгосрочных климатических прогнозов.

Для ответа на вопросы, связанные с происхождением МРТ, в первую очередь необходимо иметь количественные данные об изменении климата и газового состава атмосферы за последние 1,5-2 млн лет. Считается, что их можно получить по кернам древнего льда, залегающего в основании Восточно-Антарктического ледникового покрова [10]. Именно на это будет нацелен новый международный проект глубокого бурения в Антарктиде, предложенный научной организацией Международное партнёрство в изучении ледяных кернов (International Partnerships in Ice Core Sciences IPICS, cм. http://www.pages-igbp.org/ini/end-aff/ ipics/intro). Вместе с тем полезная информация, касающаяся причин МРТ, может содержаться в уже имеющемся керне, поднятом из буровой скважины на станции Восток. Всю колонку этого керна можно разделить на три части. Верхние 3310 м керна сложены атмосферным льдом с первоначальной последовательностью 
залегания ледяных слоёв. Анализ данной части керна впервые позволил реконструировать изменения климата и газового состава атмосферы за последние 420 тыс. лет [31]. Интервал керна между 3310 и 3539 м сложен атмосферным льдом, стратиграфия которого, как полагают, нарушена в результате образования складок различных масштабов и перемешивания льда в придонных слоях ледника [18, 36, 39-41]. Нижние 230 м керна (3539-3769 м) сложены конжеляционным льдом, образовавшимся из воды подледникового оз. Восток.

В работе анализируются опубликованные и вновь полученные нами результаты исследований атмосферного льда с несогласным залеганием слоёв из интервала глубин 3310-3539 м. Предварительные оценки возраста придонных слоёв льда, сделанные с использованием метода датирования, основанного на росте включений клатратных гидратов воздуха во льду, показывают, что возраст атмосферного льда вблизи его контакта с озёрным льдом может превышать 1,5 млн лет [3]. В результате выполненных нами измерений газосодержания этого льда установлено, что высота поверхности ледникового покрова в центральной части Восточно-Антарктического ледникового покрова была стабильной и близкой к современной весь период формирования изученной 3539-метровой толщи атмосферного льда (>1,5 млн лет?). Последнее подтверждает результаты моделирования коле- баний размеров ледникового покрова Антарктиды за последние 5 млн лет [32].

Анализ предварительных результатов, полученных при изучении керна со станции Восток в интервале 3310-3539 м, не вызывает сомнения в том, что комплексное исследование керна может дать очень важную информацию как о генезисе МРТ, так и о тех методических трудностях, которые ожидают исследователей нового керна, который будет получен при реализации будущего международного проекта. В связи с этим мы предлагаем и обосновываем программу нового проекта исследований древнейшего антарктического льда со станции Восток под общим названием Vostok Oldest Ice Challenge (VOICE). K первоочередным задачам этого проекта относятся: 1) уточнение датировки древнейшего льда с помощью новых методов изотопного датирования, основанных на использовании изотопов ${ }^{40} \mathrm{Ar} /{ }^{38} \mathrm{Ar}$ [5] и ${ }^{26} \mathrm{Al} /{ }^{10} \mathrm{Be}[4]$; 2) измерение концентрации $\mathrm{CO}_{2} \mathrm{c}$ целью получения первых данных о концентрации этого парникового газа в атмосфере Земли 1-2 млн л.н.; 3) измерение изотопного состава льда с высоким разрешением, а также глобально-однородных параметров атмосферы $\left(\delta^{18} \mathrm{O}\right.$, $\mathrm{CH}_{4}$ ) для реконструкции стратиграфии «восточного» керна возрастом до 0,8 млн лет путём сопоставления полученных по нему данных с данными хорошо датированного керна со станции Конкордия (проект ЕРICA) [9, 13]. 